\title{
PENGARUH PEMBERIAN EKSTRAK KASAR DAUN BELIMBING WULUH (Averrhoa bilimbi L.) TERHADAP DAYA HAMBAT BAKTERI Pseudomonas fluorescens SECARA IN VITRO
}

\author{
Sri Andayani ${ }^{a}$, Heny Suprastyani ${ }^{a}$, dan Etika Dwi Rahmawati ${ }^{a}$ ** \\ ${ }^{a}$ Program Studi Budidaya Perairan, Fakultas Perikanan dan Ilmu Kelautan, Universitas Brawijaya Malang \\ Jl.Veteran No. 1 Malang, Indonesia \\ *Koresponden penulis : etikasasmito10@gmail.com
}

\begin{abstract}
Abstrak
Penggunaan antibiotik yang berlebihan dapat menyebabkan resistensi bakteri. Pengobatan alternatif digunakan pada ikan yang terserang penyakit oleh bakteri adalah dengan menggunakan bahan alami yang mengandung zat anti bakteri yang lebih ramah lingkungan dan tidak menimbulkan resistensi terhadap bakteri. Salah satunya adalah daun belimbing wuluh (Averrhoa bilimbi L.). Tujuan dari penelitian ini adalah untuk mengetahui pengaruh ekstrak kasar daun belimbing wuluh (A. bilimbi L.) terhadap bakteri Pseudomonas fluorescens. Metode yang digunakan pada penelitian ini yaitu metode eksperimen dengan Rancangan Acak Lengkap (RAL), Uji MIC (Minimum Inhibition Concentration) dan Uji Cakram. Pada penelitian ini terdiri dari 5 perlakuan, 2 kontrol dan 3 kali ulangan. Perlakuan yang digunakan adalah ekstrak kasar daun belimbing wuluh (A. bilimbi L.) dengan dosis 5 ppm, 25 ppm, 45 ppm, 65 ppm dan 85 ppm. Penambahan dosis diperlukan ekstrak $A$. bilimbi L. terhadap diameter zona hambat menunjukkan pola linier dengan persamaan $\mathrm{y}=3,18733+0,0287 \mathrm{x}$ dan koefisien $\mathrm{R}^{2}=0,8401$. Hasil penelitian ini dapat disimpulkan bahwa pemberian ekstrak kasar daun belimbing wuluh (Averrhoa bilimbi L.) dapat menghambat pertumbuhan bakteri yang ditunjukkan dengan pola linier yang berbanding lurus antara dosis dengan zona hambat. Penelitian ini diperlukan penelitian lanjutan untuk diaplikasikan pada ikan secara in vivo dengan dosis yang optimal.
\end{abstract}

Kata Kunci: Daun Belimbing Wuluh, Pseudomonas fluorescens, Uji MIC, Uji Cakram

\begin{abstract}
Excessive antibiotic treatment could be caused by bacterial resistance. The alternative treatment used in fish attacked by bacteria was using natural ingredients that contained antibacterial substances which more environmental friendly and did not cause resistance to bacteria, one of the natural ingredients is the leaves of star fruit. Based on the problems, it was necessary to research the effect of starfruit leaves crude extract on Pseudomonas fluorescens. The purpose of this study was to determine the effect of starfruit (Averrhoa bilimbi L.) leaves crude extract on P. fluorescens. The method used in this study was the experimental method with Completely Randomized Design (CRD), using the MIC (Minimum Inhibition Concentration) and Disc Test. This study consisted of 5 treatments, 2 controls, and 3 replications. The treatment used the crude extract of star fruit leaves (A. bilimbi L.) at a dose of 5 ppm, 25 ppm, 45 ppm, 65 ppm, and 85 ppm. The addition of the doses required by A. bilimbi L. extract on the diameter of the inhibitory zone showed a linear pattern with the equation $y=3.18733+0.0287 x$ and the coefficient $R 2=$ 0.8401. The result showed the crude extract of star fruit leaves (Averrhoa bilimbi L.) could inhibit bacterial growth that showed by a directly proportional linear pattern between doses and inhibition zone. This research needed advanced research in applying to the fish by in vivo method in optimal dose.
\end{abstract}

Keywords: Starfruit Leaves, Pseudomonas fluorescens, MIC Test, Disc Test

\section{PENDAHULUAN}

Indonesia merupakan negara yang mempunyai sumber daya alam yang melimpah. Salah satu diantaranya adalah sumber daya perairan, baik tawar, laut maupun payau yang menunjang pembangunan perikanan sehingga dapat meningkatkan devisa negara. Peningkatan usaha budidaya menyebabkan adanya arus perpindahan produk tersebut sehingga akan mengakibatkan 
perpindahan hama dan penyakit ikan dan tersebar ke daerah lain yang dapat menimbulkan kerugian yang sangat besar [1].

Peningkatan permintaan produk perikanan untuk kebutuhan domesik maupun ekspor saat ini telah menempatkan sektor perikanan pada posisi yang penting. Potensi pengembangan budidaya perikanan sangat besar yang menyebabkan intensifikasi semakin menjadi pilihan. Intensifikasi budidaya sering menyebabkan menurunnya kondisi lingkungan yang pada akhirnya menimbulkan penyakit. Penyakit yang disebabkan oleh bakteri selain dapat menyebabkan kematian masal juga mengganggu kualitas ikan dengan menurunkan mutu daging ikan yang terinfeksi sehingga minat konsumen menurun. Beberapa kasus wabah penyakit akibat infeksi bakteri telah menyebabkan pembudidaya mengalami kerugian besar, oleh karena itu diperlukan penanganan penyakit yang serius [2].

Menurut [3], Penyakit yang disebabkan oleh bakteri merupakan masalah utama yang dihadapi para pembudidaya ikan. Bakteri yang menyebabkan penyakit pada ikan adalah $P$. fluorescens. Bakteri ini disebut sebagai agen penyebab penyakit bakterial Hemorrhagic septicemia dari ikan budidaya. Bakteri ini dianggap sebagai patogen utama ikan air tawar dan patogen oportunistik untuk spesies ikan yang berbeda yang dibudidayakan di perairan laut dan air payau di seluruh dunia. Penanganan penyakit ini banyak dilakukan dengan menggunakan antibiotik. Namun, antibiotik dapat menyebabkan resistensi bakteri dan dampak buruk bagi lingkungan perairan.

Pengobatan alternatif digunakan pada ikan yang terserang penyakit yang disebabkan oleh bakteri adalah dengan menggunakan bahan - bahan alami yang mengandung zat anti bakteri yang lebih ramah lingkungan dan tidak menimbulkan resistensi terhadap bakteri. Salah satunya adalah daun belimbing wuluh (A. bilimbi L.). Menurut [4], daun belimbing wuluh (A. bilimbi $L$ ) mengandung zat-zat aktif yang berperan sebagai zat anti bakteri. Senyawa-senyawa kimia tersebut diantaranya adalah Tanin, Flavonoid, Glukosida, Asam Formiat, Asam Sitrat, dan beberapa mineral (terutama Kalsium dan Kalium). Salah satu fungsi dari Flavonoid dan
Tanin adalah kerjanya sebagai antibakteri. Zat-zat tersebut merupakan senyawa aktif dalam tanaman yang berkhasiat sebagai obat yang dapat menyembuhkan penyakit infeksi yang disebabkan oleh bakteri. Sedangkan menurut [5], ekstrak daun belimbing wuluh mengandung flavonoid, saponin, triterpenoid dan tanin. Flavonoid bekerja dengan cara denaturasi protein. Proses ini juga menyebabkan gangguan dalam pembentukan sel sehingga merubah komposisi komponen protein. Fungsi membran sel yang terganggu dapat menyebabkan peningkatan permeabilitas sel, diikuti dengan terjadinya kerusakan sel bakteri. Kerusakan tersebut menyebabkan kematian sel bakteri.

Daun belimbing wuluh memiliki kandungan flavonoid, saponin, tanin, sulfur, asam format, peroksidase, kalsium oksalat, dan kalium sitrat. Zat aktif pada daun belimbing wuluh memiliki aktivitas antibakteri terhadap bakteri Escherichia coli dan Staphylococcus aureus [6].

Berdasarkan masalah tersebut maka perlu dilakukan penelitian terhadap pengaruh ekstrak daun belimbing wuluh (Averrhoa bilimbi L.) terhadap bakteri Pseudomonas fluorescend yang dapat berperan sebagai alternatif penggunaan antibiotik yang lebih aman bagi lingkungan dan memiliki residu yang lebih sedikit dari pada antibiotik. Selain itu juga mengurangi resistensi ikan terhadap antibiotik yang diberikan.

Penelitian ini dilakukan untuk mengetahui pengaruh pemberian ekstrak kasar daun belimbing wuluh (A. bilimbi L.) terhadap daya hambat dari bakteri $P$. fluorescens. Penelitian ini diharapkan mampu memberikan informasi bagi perkembangan dunia perikanan dan masyarakat luas. 


\section{MATERI DAN METODE}

Penelitian ini dilakukan di Laboratorium Ilmu Teknologi Hasil Perairan Divisi Keamanan Hasil Perikanan dan Laboratorium Eksplorasi Sumberdaya Perikanan dan Kelautan Fakultas Perikanan dan Ilmu Kelautan, Universitas Brawijaya, Malang.

Metode penelitian yang digunakan adalah metode eksperimen dengan rancangan penelitian yang digunakan adalah Rancangan Acak Lengkap (RAL). Penelitian terdiri dari 5 perlakuan dan 2 kontrol dengan 3 kali ulangan. Perlakuan yang digunakan adalah pemberian ekstrak A. bilimbi L. sebagai daya hambat bakteri P. fluorescens. Perlakuan A (5 $\mathrm{ppm})$, perlakuan B (25 ppm), perlakuan C (45 $\mathrm{ppm})$, perlakuan D (65 ppm), dan perlakuan $\mathrm{E}$ (85 ppm). Selain itu, pada perlakuan kontrol positif yaitu tetracycline $30 \mathrm{ppm}$ dan kontrol negatif (tanpa penambahan ekstrak).

Alat-alat yang digunakan pada penelitian ini antara lain: cawan petri, tabung reaksi, pipet volume, bola hisap, jangka sorong, rotary vacum evaporator, spatula, gunting, vortex mixer, blue tip, laminary air flow, hot plate, lemari pendingin, jarum ose, oven, autoklaf, inkubator, mikropipet, rak tabung reaksi, gelas ukur, beaker glass, pinset, sprayer, nampan, corong kaca, spatula, erlenmeyer, cotton swab, bunsen, botol film, toples kaca 15 liter, timbangan digital, blender, spektrofotometer, lap kering.

Bahan-bahan yang digunakan pada penelitian ini antara lain : daun belimbing wuluh (A. bilmbi L.), bakteri $P$. fluorescens, ethanol 96\%, Media NB, Media PSA, DMSO $10 \%$, alkohol $70 \%$, akuades, spirtus, kertas label, kertas saring, kapas, aluminium foil, plastik wrap, benang kasur, tisu, kertas cakram, vaseline, kertas bekas, sarung tangan, korek api.

\section{Pembuatan Ekstrak Kasar Daun Belimbing Wuluh (A. bilimbi L.)}

Pembuatan ekstrak dilakukan dengan cara proses maserasi dan evaporasi. Daun belimbing wuluh sebanyak 250 gr dimaserasi dengan menggunakan larutan etanol 96\% dengan perbandingan 1:6 selama $3 \times 24$ jam yang kemudian disaring dan dipekatkan menggunakan rotary vacum evaporator dengan suhu $50^{\circ} \mathrm{C}$ sampai mendapatkan hasil ekstrak berupa pasta, lalu hasil ekstrak ditimbang.

\section{Pembuatan Media Uji Agar Miring}

Media PSA (Pseudomonas Selective Agar) ditimbang 0,48 g dengan menggunakan timbangan digital. Media dimasukkan ke dalam erlenmeyer, kemudian dilarutkan dengan aquades sebanyak $10 \mathrm{ml}$ dan dihomogenkan. Tabung reaksi ditutup kapas dan dibungkus alumunium foil serta diikat dengan tali. Media disterilisasi dengan autoklaf pada suhu $121^{\circ} \mathrm{C}$ selama 15 menit dengan tekanan 1 atm. Tabung reaksi yang berisi media steril dimiringkan dengan kemiringan $30^{\circ}$ dan ditunggu hingga padat. Media yang telah padat kemudian dilakukan strike dalam keadaan steril.

\section{Kultur Bakteri}

Media NB (Nutrient Broth) ditimbang $0,08 \mathrm{~g}$ dengan menggunakan timbangan digital dan dimasukkan ke dalam erlenmeyer. Media dilarutkan dengan aquades $10 \mathrm{ml}$ lalu dihomogenkan. Media yang sudah homogen ditutup kapas dan ditutup dengan aluminium foil kemudian diikat dengan tali, media disterilisasi dengan autoklaf pada suhu $121^{\circ} \mathrm{C}$ selama 15 menit dengan tekanan $1 \mathrm{~atm}$.

\section{Uji MIC (Minimum Inhibition Concentration)}

Media NB ditimbang 0,4 g dengan menggunakan timbangan digital dan dimasukkan ke dalam erlenmeyer. Media dilarutkan dengan aquades $50 \mathrm{ml}$ dan dihomogenkan. Setelah homogen, larutan dituang kedalam 10 tabung reaksi masingmasing sebanyak $5 \mathrm{ml}$. Masing-masing tabung reaksi kemudian ditutup kapas dan ditutup dengan aluminium foil kemudian diikat dengan tali, kemudian media disterilisasi dengan autoklaf pada suhu $121^{\circ} \mathrm{C}$ selama 15 menit dengan tekanan $1 \mathrm{~atm}$. 


\section{Uji Cakram}

Media PSA ditimbang 4,84 g dengan menggunakan timbangan digital. Media dimasukkan kedalam erlenmeyer, kemudian dilarutkan dengan aquades sebanyak $100 \mathrm{ml}$ dan dihomogenkan. Erlenmeyer ditutup kapas dan dibungkus alumunium foil serta diikat dengan tali. Media disterilisasi dengan autoklaf pada suhu $121^{\circ} \mathrm{C}$ selama 15 menit dengan tekanan 1 atm. Media dituang kedalam 4 cawan petri dengan masing-masing cawan diisi $\pm 25 \mathrm{ml}$ yang dilakukan didalam LAF (Laminar Air Flow) untuk menghindari kontaminasi dari bakteri lain, ditunggu hingga memadat.

\section{Peremajaan Bakteri}

Peremajaan bakteri dilakukan dalam keadaan steril, dengan menginokulasi kembali isolat bakteri P. fluorescens menggunakan jarum ose bulat yang telah dipanaskan diatas bunsen dan digores pada media agar miring secara zig-zag dalam kondisi yang steril kemudian diinkubasi pada suhu $32^{\circ} \mathrm{C}$ selama 24 jam.

\section{Kultur Bakteri}

Prosedur dalam kultur bakteri yaitu biakan bakteri yang sudah diremajakan pada media agar miring diambil dengan menggunakan jarum ose sebanyak 1 gores dalam keadaan steril. Kemudian ose yang berisi bakteri dicelupkan pada media yang sudah di persiapkan. Media disimpan pada inkubator dengan suhu $32^{\circ} \mathrm{C}$ selama 24 jam.

\section{HASIL DAN PEMBAHASAN}

\section{Uji MIC (Minimun Inhibition Concentration)}

Uji MIC (Minimum Inhibition concentration) dilakukan dengan berbagai macam dosis menggunakan ekstrak kasar daun belimbing wuluh (A. bilimbi L.) dengan menggunakan pelarut DMSO yang bertujuan untuk mengetahui dosis terkecil dalam menghambat bakteri P. fluorescens.

Hasil pengamatan uji MIC ekstrak daun belimbing wuluh (A. bilimbi L.) disajikam pada Tabel 1.
Tabel 1. Hasil Pengamatan Uji MIC

\begin{tabular}{lccl} 
No & $\begin{array}{l}\text { Konsentras } \\
\text { i }\end{array}$ & \multicolumn{3}{l}{$\begin{array}{l}\text { Absorbans } \\
\text { i }\end{array}$} & Warna \\
\hline 1. & 2 & 0,214 & Keruh \\
2. & 3 & 0,210 & Keruh \\
3. & 4 & 0,205 & $\begin{array}{l}\text { Agak } \\
\text { Bening }\end{array}$ \\
& & & Benin \\
4. & $\mathbf{5}$ & $\mathbf{0 , 1 9 1}$ & g \\
& & & \\
5. & 6 & 0,189 & Bening \\
6. & 7 & 0,183 & Bening \\
7. & 8 & 0,178 & Bening \\
8. & 9 & 0,175 & Bening \\
9. & $\mathrm{K}(+)$ & 0,193 & Bening \\
10. & $\mathrm{K}(-)$ & 0,258 & Keruh \\
\hline
\end{tabular}

Keterangan:

Kontrol (+) : Tetracycline $30 \mathrm{ppm}$

Kontrol (-) : tanpa pemberian ekstrak

Hasil Uji MIC didapatkan dari pengukuran nilai absorbansi menggunakan spektrofotometer. Dosis MIC yang digunakan adalah 5 ppm karena nilai yang dihasilkan mendekati kontrol positif dan warna media dalam tabung menjadi bening. Hal ini dikarenakan ekstrak kasar daun belimbing wuluh (A. bilimbi L.) memiiliki senyawa antibakteri yang mampu menghambat bakteri P. fluorescens.

Pada uji MIC tidak hanya dilakukan dengan menggunakan indikator absorbansi namun juga dapat dilihat dari perubahan warna. Menurut [7], Penentuan MIC dapat dilihat berdasarkan pengamatan kekeruhan atau kejernihan sampel pada seluruh tabung reaksi dan membandingkannya dengan kontrol.

Hasil uji MIC kejernihan sampel yang mendekati kontrol positif mengindikasikan bahwa ekstrak mampu menghambat pertumbuhan bakteri. Dari hasil spektrofotometer didapatkan bahwa konsentrasi 5 ppm menghasilkan warna yang mendekati kontrol positif. Hal tersebut menunjukkan bahwa 5 ppm merupakan dosis MIC. Hasil uji MIC dapat dilihat pada Gambar 1. 


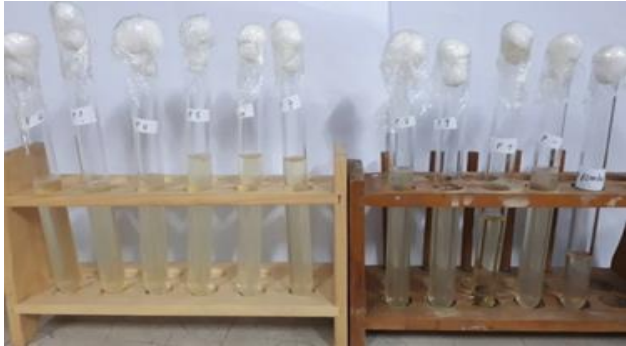

Gambar 1. Hasil Uji MIC (Minimum Inhibiting Concentration)

\section{Uji Cakram}

Uji cakram dilakukan dengan menggunakan perlakuan dosis $5 \mathrm{ppm}, 25 \mathrm{ppm}$, $45 \mathrm{ppm}, 65 \mathrm{ppm}, 85 \mathrm{ppm}$, kontrol positif dan kontrol negatif. Dosis tersebut diperoleh dari uji MIC sebesar 5 ppm yang mana sudah mampu menghambat pertumbuhan bakteri $\mathrm{P}$. fluorescens. hasil uji daya hambat bakteri P. fluorescens setelah pemberian ekstrak kasar daun belimbing wuluh (A. bilimbi $\quad$ L.) disajikan pada Gambar 2.

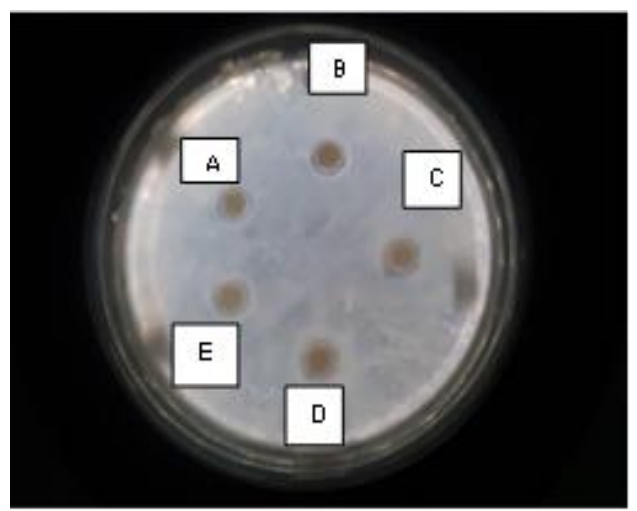

Gambar 2. Hasil Uji Cakram

Hasil uji cakram dari ekstrak daun belimbing wuluh (A. bilimbi L.) dengan lima perlakuan dosis dan tiga kali ulangan yang dilakukan, didapatkan diameter zona bening setelah dilakukan pengamatan 24 jam seperti yang disajikan pada Tabel 2.

Tabel 2. Hasil Rata - Rata Zona Hambat Bakteri Konsentrasi ekstrak Rata - rata diameter

$$
\text { (ppm) }
$$
zona hambat $(\mathrm{mm})$

$\begin{array}{cc}\text { A (5 ppm) } & 3,29^{\mathrm{a}} \\ \text { B (25 ppm) } & 4,09^{\mathrm{b}} \\ \text { C (45 ppm) } & 4,39^{\mathrm{bc}} \\ \text { D (65 ppm) } & 4,83^{\text {cd }} \\ \text { E (85 ppm) } & 5,79^{\mathrm{e}}\end{array}$

Berdasarkan hasil di atas, hasil rata rata zona hambat yang tertinggi yaitu perlakuan dengan konsentrasi ekstrak 85 ppm sebesar $5,79 \mathrm{~mm}$, sedangkan rata - rata diameter zona bening terendah diperoleh konsentrasi ekstrak 5 ppm sebesar 3,29 mm.

Hubungan antara konsentrasi ekstrak daun belimbing wuluh (A. bilimbi L.) dengan zona hambat yang diperoleh dari hasil analisis regresi disajikan berupa grafik yang dapat dilihat pada Gambar 3.

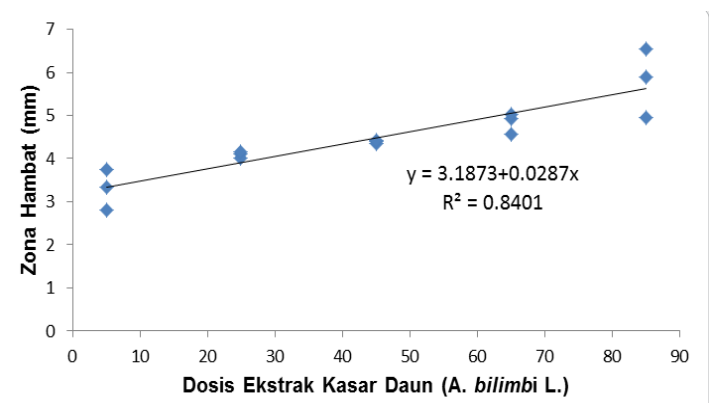

Gambar 3. Grafik Hubungan Zona Hambat

Berdasarkan Gambar 3, terlihat hubungan antara penambahan dosis perlakuan ekstrak A. bilimbi L. terhadap diameter zona hambat menunjukkan pola linier dengan persamaan persamaan $\mathrm{y}=3,18733+0,0287 \mathrm{x}$ dan koefisien $\mathrm{R}^{2}=0,8401$. Hubungan antara pemberian ekstrak kasar daun belimbing wuluh (A. bilimbi L.) dalam menghambat pertumbuhan bakteri P. fluorescens menunjukkan respon yang meningkat seiring dengan bertambahnya dosis ekstrak.

Uji MIC dan uji cakram yang telah dilakukan menunjukkan bahwa ekstrak daun belimbing wuluh (A. bilimbi L.) mampu menghambat pertumbuhan bakteri P. fluorescens hal tersebut dapat dilihat dari zona hambat yang terbentuk. Bahan aktif juga berperan penting dalam menghambat $P$. fluorescens. Bahan aktif yang terkandung pada daun belimbing wuluh (A. bilimbi L.) flavonoid, alkaloid, saponin dan tanin.

Menurut [8], Flavonoid bekerja dengan cara denaturasi protein. Proses ini juga menyebabkan gangguan dalam pembentukan sel sehingga merubah komposisi komponen protein. Fungsi membran sel yang terganggu dapat menyebabkan peningkatan permeabilitas sel, diikuti dengan terjadinya kerusakan sel bakteri. Kerusakan tersebut menyebabkan kematian sel bakteri. Senyawa tanin merupakan senyawa turunan fenol yang 
secara umum mekanisme antimikrobanya dari senyawa fenol. Tanin merupakan growth inhibitor, sehingga banyak mikroorganisme yang dapat dihambat pertumbuhannya oleh tanin. Tanin mempunyai target pada polipeptida dinding sel. Senyawa ini merupakan zat kimia yang terdapat dalam tanaman yang memiliki kemampuan menghambat sintesis dinding sel bakteri dan sintesis protein sel kuman gram positif maupun gram negatif.

Menurut [9], Ketersediaan alkaloid dapat mengganggu terbentuknya komponen penyusun peptidoglikan pada sel bakteri, sehingga dapat mengakibatkan sel bakteri menjadi lisis. Menurut [10], Aktivitas saponin dalam menghambat pertumbuhan bakteri yaitu dengan mengganggu kerja enzim dan merusak membrane sitoplasma yang berakibat pada terhambatnya transport nutrisi yang pada akhirnya menyebabkan kematian bakteri.

Hasil penelitian dilakukan untuk mengetahui pengaruh pemberian ekstrak kasar daun belimbing wuluh (Averrhoa bilimbi L.) terhadap daya hambat pertumbuhan bakteri $P$. fluorescens secara in vitro. Penelitian ini diperlukan penelitian lanjutan untuk diaplikasikan pada ikan secara in vivo dengan dosis yang optimal.

\section{KESIMPULAN}

Penelitian dapat disimpulkan bahwa pemberian ekstrak kasar daun belimbing wuluh (A. bilimbi L.) dapat menghambat bakteri $P$. fluorescens dan hasil zona hambat tertinggi terdapat pada perlakuan $\mathrm{E}$ dengan dosis 85 ppm dengan nilai rata - rata zona hambat sebesar $5,79 \mathrm{~mm}$.

\section{DAFTAR PUSTAKA}

[1] Sukarni,Maftuch dan H.Nursyam, "Kajian Penggunaan Ciprofloxacin terhadap Histologi Insang dan Hati Ikan Botia (Botia macracanthus, Bleeker) yang Diinfeksi Bakteri Aeromonas hydrophila", J.Exp. Life Sci, vol. 2 no. 1, hal. 6-12, 2012.

[2] Gardenia, L., I. Koesharyani, H. Supriyadi, dan T. Mufidah, "Aplikasi deteksi aeromonas hydrophila penghasil aerolysin dengan menggunakan polymerase chain reaction (pcr)", Prosiding forum inovasi teknologi akualultur, hal.877-883, 2010.

[3] Foysal M.J., M.M. Rahman, dan M Alam, "Antibiotic sensitivity and in vitro antimicrobial activity of plant extracts to P.fluorescens isolates collected from diseased fish", International Journal of Natural Sciences, vol.1, no. 4, hal. 82-88. 2011.

[4] Afifi,R., E. Erlin, dan J. Rachmawati, "Uji anti bakteri ekstrak daun belimbing wuluh (A. bilimbi L) terhadap zona hambat bakteri jerawat Propionibacterium acnes secara in vitro", Quangga. vol.10, no.1, hal.1118, 2018.

[5] Liantari, D. S, "Effect of wuluh starfruit leaf extract for Streptococcus mutans growth", J Majority, vol. 3, no. 7, hal. 27-33, 2014.

[6] Pendit P. A. C. D., E. Zubaidah, dan F. H. Sriherfyna, "Karakteristik fisik kimia dan aktivitas antibakteri ekstrak daun belimbing wuluh (A. bilimbi L.)", Jurnal Pangan dan Agroindustri, vol. 4, no. 1, hal. 400-409. 2016.

[7] Putri, R. W., W, Tjajaningsih dan D, Handijatno, "Daya antibakteri pigmen pyocyanin dari isolate Pseudomonas aeruginosa terhadap Aeromonas hydrophila secara in vitro", Jurnal berkala ilmiah perikanan, vol. 3, no.1, hal. 65-73, 2008.

[8] Saputra,O., N. Anggraini, "Khasiat belimbing wuluh (A. bilimbi L.) terhadap penyembuhan Acne Vulgaris. Majority, vol. 5, no. 1, hal. 76-80, 2016.

[9] Maliana, Y., S. Khotimah, F. Diba, "Aktivitas antibakteri kulit Garcinia mangostana Linn. Terhadap pertumbuhan Flavobacterium dan Enterobacter dari Coptotermes curvignathus Holmgren", Protobiont, vol. 2, no. 1, hal. 7 - 11, 2013. 
[10] Wila, H., F. Yusro, Y. Mariani "Skrining fitokimia dan aktivitas antibakteri ekstrak kulit batang (Eusideroxylon zwageri) terhadap Escherichia coli dan Salmonella typhi", Jurnal Tengkawang, vol. 8, no. 1, hal. $38-49,2018$. 